\title{
Colorectal Cancer pTis TNM Finding v8
}

National Cancer Institute

\section{Source}

National Cancer Institute. Colorectal Cancer pT is TNM Finding v8. NCI Thesaurus. Code C134159.

Colorectal cancer with a finding of carcinoma in situ, intramucosal carcinoma

(involvement of lamina propria with no extension through muscularis mucosae). (from AJCC 8th Ed.) 